IIIIIIIIIIIIIIIIIIIIIIIIIIII

ミニレビュー

|IIIIIIIIIIIIIIIIIIIIIIIIIIII

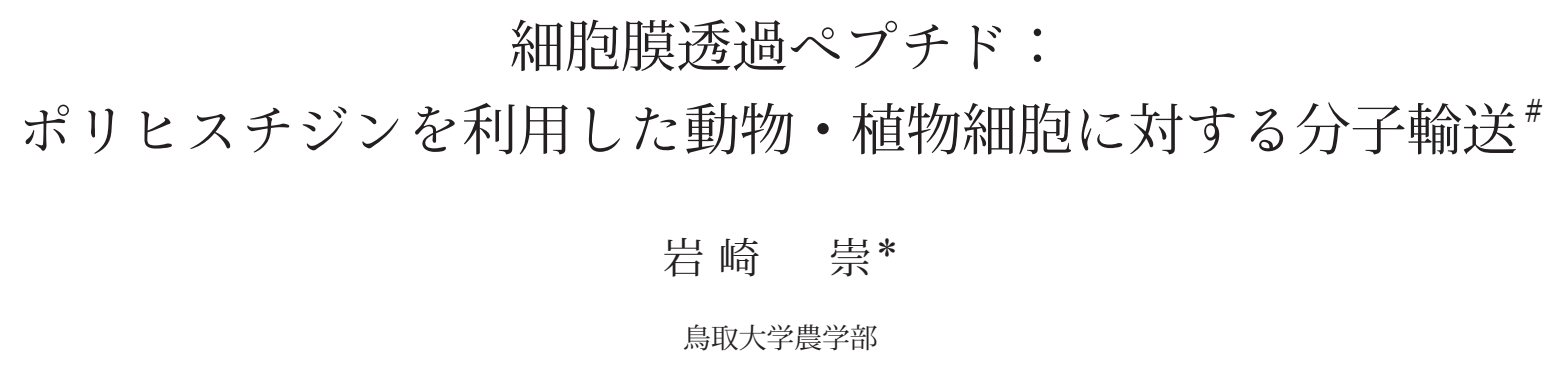

（2018年12月29日受理）

\title{
Molecular delivery into mammalian and plant cells using new cell-penetrating peptide "PolyHis"
}

\author{
Takashi IwASAKI
}

Faculty of Agriculture, Tottori University, Tottori 680-8553, Japan

Keywords: cell-penetrating peptide, histidine, drug delivery, mammalian cells, plant cells.

\section{は じめに}

細胞膜透過ペプチド（CPP: Cell-penetrating peptide）は 核酸やタンパク質の細胞内輸送キャリアーとして, 現在幅広 い分野で利用されている. 近年, 100 種を超える CPPが報告 されており，これらはアルギニンやリジンといった塩基性ア ミノ酸を豊富に含有することが知られている。代表的な例 として Penetratin(RQIKIWFQNRRMKWKK-NH ${ }_{2}$ ), ${ }^{1)} \mathrm{HIV}$ Tat (48-60) (GRKKRRQRRRPPQ- $\mathrm{NH}_{2}$ ), ${ }^{2)}$ Octa-arginine (R8) (RRRRRRRR- $\left.\mathrm{NH}_{2}\right)^{3)}$ などが世界的に有名な CPP とし て挙げられる。これらのCPPは生理的条件下で高密度の正 電荷を帯び, 細胞表面の負電荷を帯びた糖鎖と相互作用す ることにより，細胞膜を透過することが報告されている. ${ }^{4-6)}$ すなわち, CPPにとって正電荷は重要な原動力であると考 えられている.

筆者らは, この細胞膜透過ペプチドを利用して, 様々な応

\footnotetext{
\#第43回大会シンポジウムを取りまとめた解説.

* \% 680-8553 鳥取県鳥取市湖山町南4-101

E-mail: itaka@tottori-u.ac.jp

(C) 日本農薬学会
}

用技術の創生に挑戦している.その一環として, 腫瘍組織 を標的とした細胞膜透過ペプチドの開発を試みた. 本稿で 紹介させていただく『細胞膜透過ペプチド：ポリヒスチジン (PolyHis)』は，その過程で発見されたものである．以下に， PolyHisの発見の経緯と PolyHisの分子輸送能, そしてそれ を利用した応用技術について具体的に紹介をさせていただ $<$.

\section{PolyHisの発見の経緯}

当初, 筆者らは腫瘍組織を標的とした薬物輸送キャリアー を創生するために, 腫瘍組織に選択的な CPP の開発に取り 組んでいた，腫瘍組織を標的とする際に, 筆者らは腫瘍組織 内で特異的に形成される『低 $\mathrm{pH}$ 環境』を標的とした. 腫瘍 組織内で低 $\mathrm{pH}$ 環境が形成されるメカニズムは次の通りであ る.まず，腫瘍組織では無秩序な血管・組織形成が行われる ため, その内部が低酸素状態（Hypoxia）にあることが知ら れている.ゆえに, 腫瘍組織の内部では嫌気呼吸が克進し, 酸性代謝産物が蓄積していることがわかっている．そのた め, 腫瘍組織内部は低 $\mathrm{pH}$ (弱酸性) 環境にあることが報告 されている. ${ }^{7,8)}$ 近年では,この腫瘍組織内部の微小環境であ る低 $\mathrm{pH}$ 環境を標的とした薬物輸送技術の開発が盛んに進め 
A)
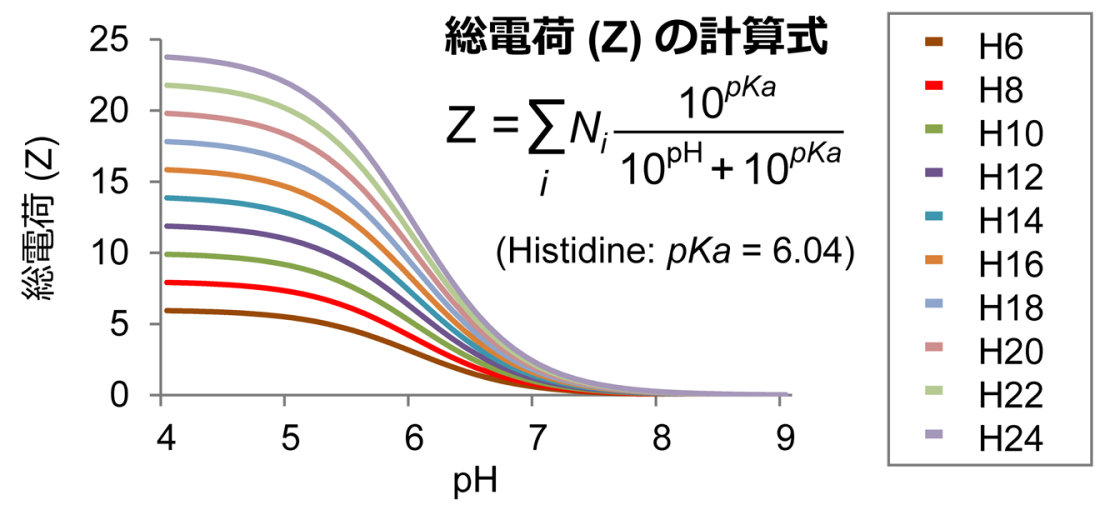

B)

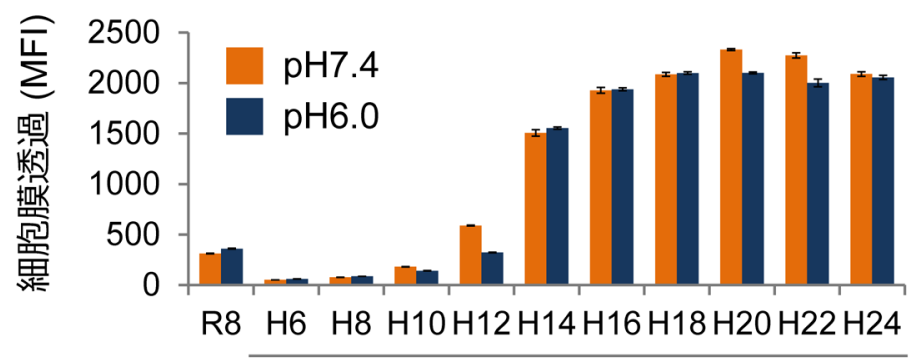

PolyHis

図 1. PolyHis の電荷と細胞膜透過.（A）PolyHis の鎖長と $\mathrm{pH}$ 環境と電荷（Z）の相関図.（B）生理的 $\mathrm{pH}$ 条件（pH7.4）および低pH条件 （pH 6.0）における PolyHisの細胞膜透過. HepG2細胞（ヒト肝癌細胞）に対するPolyHisの細胞膜透過をフローサイトメーターにより定量 解析した。

\section{られている.}

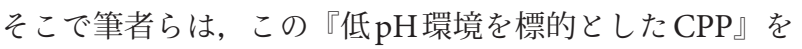
開発することで, 『腫瘍組織に選択的な $\mathrm{CPP}$ を作れるので はないかと考えた。低 $\mathrm{pH}$ 環境を標的としたCPPを設計す るにあたり，筆者らは低 $\mathrm{pH}$ 環境で限定的に機能発現をする CPPの設計を目指した. 前述の通り, $\mathrm{CPP}$ 原動力は正電 荷であることが広く知られているため, 低 $\mathrm{pH}$ 環境で限定的 に正電荷を帯びるぺプチドを設計することができれば，低
$\mathrm{pH}$ 選択的な CPP として機能するのではないかと考えた．そ こで，筆者らは低 $\mathrm{pH}$ 選択的な $\mathrm{CPP}$ を設計するために，ヒ スチジンを利用することにした．ヒスチジンは側鎖にイミ ダゾール基を有しており, 側鎖の解離定数 $\mathrm{p} K_{\mathrm{a}}=6.04$ である ため, 生理的 $\mathrm{pH}$ 条件下では電荷的に中性である一方で, 低 $\mathrm{pH}$ 条件下では正電荷を帯びる性質を有している。四えに, ヒスチジンを低 $\mathrm{pH}$ 応答性のトリガーとして利用すること で, 低 $\mathrm{pH}$ 選択的に正電荷を带びるぺプチド（すなわち，低

表 1. PolyHisのアミノ酸配列と電荷. すべてのPolyHisは，N末端をTetramethylrhodamine(TAMRA）標識し，C末端をアミド化修飾した 状態で化学合成した。生理的 $\mathrm{pH}$ 条件（pH7.4）および低 $\mathrm{pH}$ 条件（pH6.0）におけるPolyHisの電荷は, 図 1Aの計算式を用いて算出した.

\begin{tabular}{|c|c|c|c|}
\hline \multirow{2}{*}{ PolyHis } & \multirow{2}{*}{ Sequence } & \multicolumn{2}{|c|}{ Net charge } \\
\hline & & $\mathrm{pH} 7.4$ & $\mathrm{pH} 6.0$ \\
\hline H6 & TAMRA-HHHHHH-NH ${ }_{2}$ & 0.23 & 3.00 \\
\hline $\mathrm{H} 8$ & TAMRA-HHHHHHHH-NH & 0.31 & 4.00 \\
\hline $\mathrm{H} 10$ & TAMRA-HHHHHHHHHH-NH ${ }_{2}$ & 0.38 & 5.00 \\
\hline $\mathrm{H} 12$ & TAMRA-HHHHHНHНHНHН- $\mathrm{NH}_{2}$ & 0.46 & 6.00 \\
\hline H14 & TAMRA-HНHНHНHНHНHНHН-NH ${ }_{2}$ & 0.54 & 7.00 \\
\hline H16 & 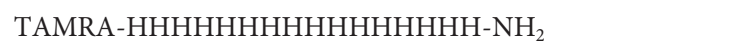 & 0.61 & 8.00 \\
\hline $\mathrm{H} 18$ & 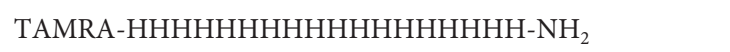 & 0.69 & 9.00 \\
\hline $\mathrm{H} 20$ & 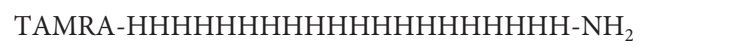 & 0.77 & 10.00 \\
\hline $\mathrm{H} 22$ & 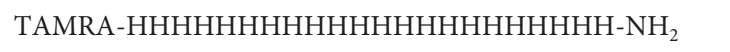 & 0.84 & 11.00 \\
\hline $\mathrm{H} 24$ & 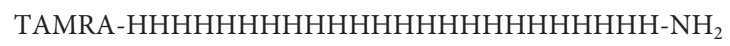 & 0.92 & 12.00 \\
\hline
\end{tabular}




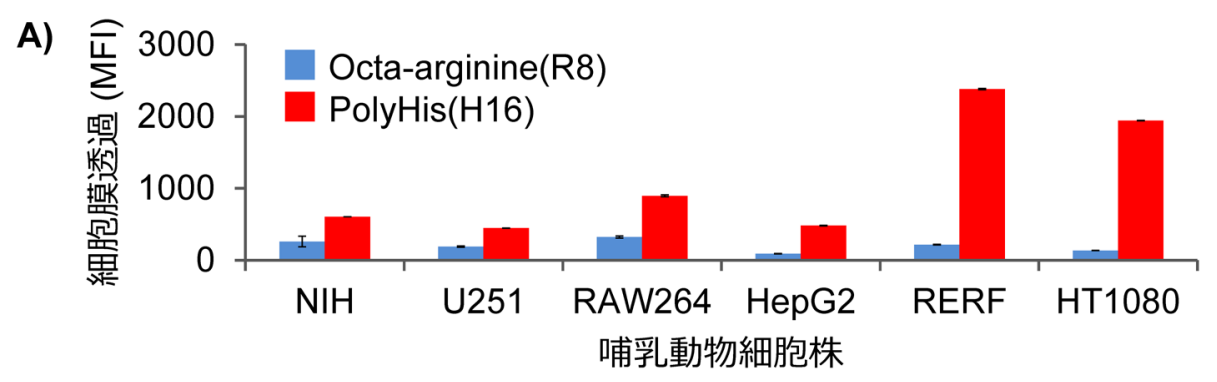

B)
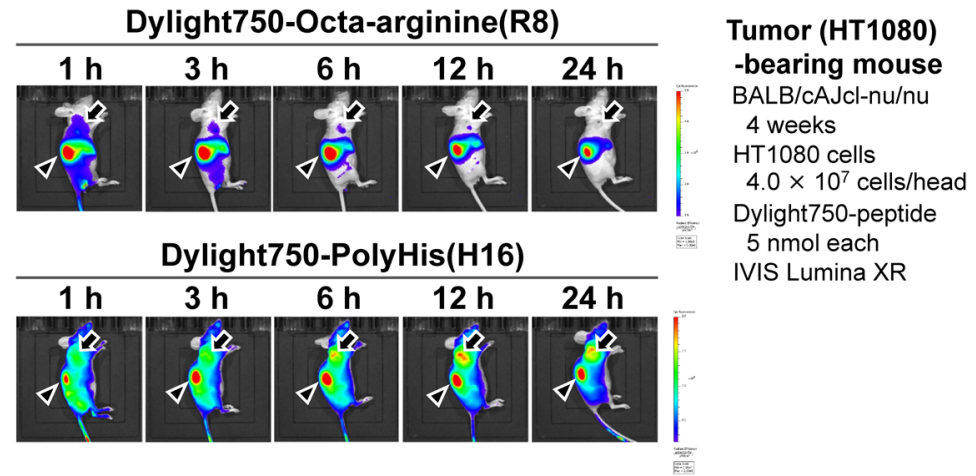

図2. PolyHis（H16）の細胞選択性.（A）In vitro細胞選択性. 比較対象として代表的な CPPである Octa-arginine（R8）を使用して，以下の 哺乳動物細胞株に対する細胞膜透過を定量した. NIH-3T3：マウス瀻維芽細胞, U251：ヒト神経膠腫細胞, RAW264：マウスマクロファー ジ, HepG2：ヒト肝癌細胞, RERF：ヒト扁平上皮肺癌細胞, HT1080：ヒト線維肉腫細胞. (B) In vivo腫瘍ターゲティング能. Dylight750 標識したOcta-arginine(R8) と PolyHis（H16）を担癌マウスの尾静脈から投与した。矢印はHT1080細胞由来の腫瘍部位を，矢頭は腎臓を示 す.

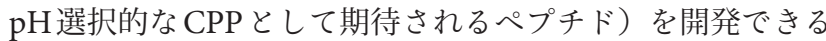
と考えた。そこで筆者らは，ヒスチジン残基のみから構成さ れる様々な鎖長のポリヒスチジン（PolyHis）を合成し, $\mathrm{pH}$ 環境と電荷と細胞膜透過能の関係性を調べることにした（図 $1 \mathrm{~A}$, 表 1 ).

最初に, HepG2細胞（ヒト肝癌細胞）を用いて, 生理的 $\mathrm{pH}$ 条件（pH 7.4）と低pH条件（pH6.0）におけるPolyHis の細胞膜透過を調べた。 その結果, 面白いことに, PolyHis を構成するヒスチジン残基数が増えるにしたがってPolyHis の細胞膜透過能は上昇し, ヒスチジン16残基の PolyHis （H16）においてピークに到達することが明らかになった. このときの細胞膜透過効率は, 代表的な CPPである Octaarginine(R8) をはるかにしのぐものであった．さらに予想 外であり, かつ極めて興味深いことに, PolyHisの細胞膜透 過は生理的 $\mathrm{pH}$ 条件（pH7.4）打よび低 $\mathrm{pH}$ 条件（pH6.0） に损いて，ほとんど差がないことが分かった（図1B). PolyHisは生理的 $\mathrm{pH}$ 条件（pH7.4）ではほとんど正電荷を 帯びない一方で, 低 $\mathrm{pH}$ 条件（pH6.0）においては高い正電 荷を帯びるぺプチドである. しかし, $\mathrm{pH}$ 条件（正電荷の有 無）に関係なく, PolyHisは細胞膜透過を示したことから， PolyHisは正電荷に依存しないCPPであることが明らかに なった。すなわち，低 $\mathrm{pH}$ 選択的な $\mathrm{CPP}$ を開発するという当 初の目的を果たすことはできなかったが，従来のCPP とは
異なる新しいタイプのCPP として PolyHis を発見するに至っ た.

\section{2. 動物細胞に対する PolyHis の分子輸送能}

前述のように，筆者らは新しいCPPとしてPolyHisを発 見した. PolyHisは代表的な CPPよりも高い細胞膜透過能を 有していることから, 有力な薬物輸送キャリアーとして利 用できることが期待された。そこで, PolyHisの動物細胞に 対する分子輸送能を明らかにするために, PolyHisのひとつ であるPolyHis(H16) について, まずは細胞選択性の解明 を試みた. 当研究室で保有している様々な哺乳動物細胞株 を使用した結果, PolyHis(H16) はRERF-LC-AI細胞（ヒト 扁平上皮肺癌細胞）やHT1080細胞（ヒト線維肉腫細胞）と いった細胞株に対して, 特に高い細胞膜透過を示すことがわ かった（図2A).さらに, HT1080細胞を移植した担癌マウ スにPolyHis（H16）を尾静脈注射により投与したところ，担 癌マウス生体内に扔いても PolyHis (H16) は腫瘍部位（線維 肉腫）に集積することが確認された（図2B）. 以上の結果か ら, PolyHis(H16) は生体内に打いて腫瘍（線維肉腫）ター ゲティング能を示す有力な薬物輸送キャリアーになり得る可 能性が示されたと言える. ${ }^{9,10)}$

さらに, PolyHisの薬物輸送技術への応用を志向し て, PolyHis(H16) の分子輸送能の解明を試みた。まず, 
PolyHis(H16) のタンパク質輸送能を明らかにするために, RFP（Red fluorescent protein）にPolyHis(H16) を融合し たRFP-H16を遺伝子工学的手法により調製した。この過程 において，RFP-H16は抗His-tag抗体を用いた Western blottingにより検出が可能であることや， Ni固定化樹脂を用い たアフィニティー精製により単離できることが確認された。 さらに，精製したRFP-H16をHT1080細胞に投与したとこ ろ，細胞内に移行することが確認された（図 $3 \mathrm{~A}$ )。すなわ ち, PolyHis(H16) をタンパク質に融合することで, 簡便な 検出・精製・細胞内導入が可能であることを示すことができ た.

次に，より高分子であり，また薬物輸送キャリアーとして も利用されているリポソームに着目し, PolyHis(H16) のリ ポソーム輸送能について評価した。まず，リポソーム表面に PolyHis（H16）を効率的に修飾するために，Stearyl基を修飾 したStearyl化 PolyHis（H16）（以下STR-H16 と呼称する）を 合成した。次いで, Fluorescein を内包したリポソーム $\{$ Dioleoyl phosphatidylcholine:Cholesterol $=10: 1(\mathrm{~mol} / \mathrm{mol})$, 粒 径約 $100 \mathrm{~nm}\}$ を調製し，このリポソームに対してSTR-H16 を処理した。リポソームの脂質二重層の疎水領域に Stearyl 基を導入することで, PolyHis(H16) 修飾リポソーム（以下 H16-Lipo と呼称する）を調製した. H16-Lipoの細胞膜透 過を調べたところ, リポソーム表面に導入するSTR-H16の 量に比例して, H16-Lipo の細胞膜透過量が増加することが 確認された（図3B)。このことから, PolyHis(H16) は粒径
約 $100 \mathrm{~nm}$ 程度のリポソームであれば，細胞内へ輸送する能 力を有していることが確認された．H16-Lipoの細胞内分布 を調べてみたところ, H16-Lipo は細胞内でゴルジ体やリソ ソームに集積することが明らかになった，実際に，我々は H16-Lipoを利用することで細胞内リソソームを標的とした 薬物輸送に成功しているが, ${ }^{11)}$ 頁数の関係上, 本稿では割愛 させていただく，以上の知見から, PolyHisは高い細胞膜透 過能と分子輸送能を有した有力な薬物輸送キャリアーである ことが示された。

\section{3. 植物細胞に対する PolyHis の分子輸送能}

前述の通り, PolyHisは多彩な応用性を秘めているCPPで あることが確認された。しかし，これらの研究成果はすべて 動物細胞を対象とした研究に由来するものであった。一方 で, 動物以外の細胞種では, 植物細胞もまた物質生産や品種 改良といった観点から産業的に利用価值の高い細胞であり, CPPの応用先としては有力な細胞種であると言える.しか し植物細胞は, 動物細胞には存在しない細胞壁を有してお りここの細胞壁が物理的障壁として CPP の応用を阻んでい る. 実際に,アルギニンまたはリジンに富んだ従来のCPP は細胞壁にトラップされてしまうため, 植物細胞に対して

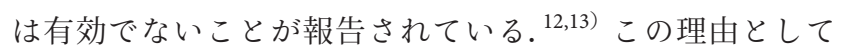
は, 負電荷に富んだ細胞壁に対して, 正電荷に富んだ従来の CPPが電荷的にトラップされてしまうためであると考えら れている.この点において, ポリヒスチジンは正電荷に依存
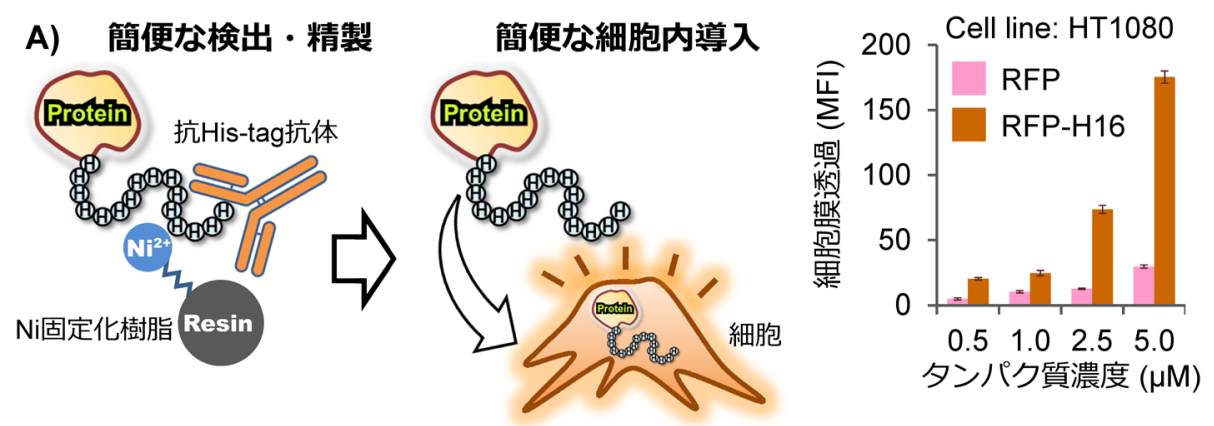

B)

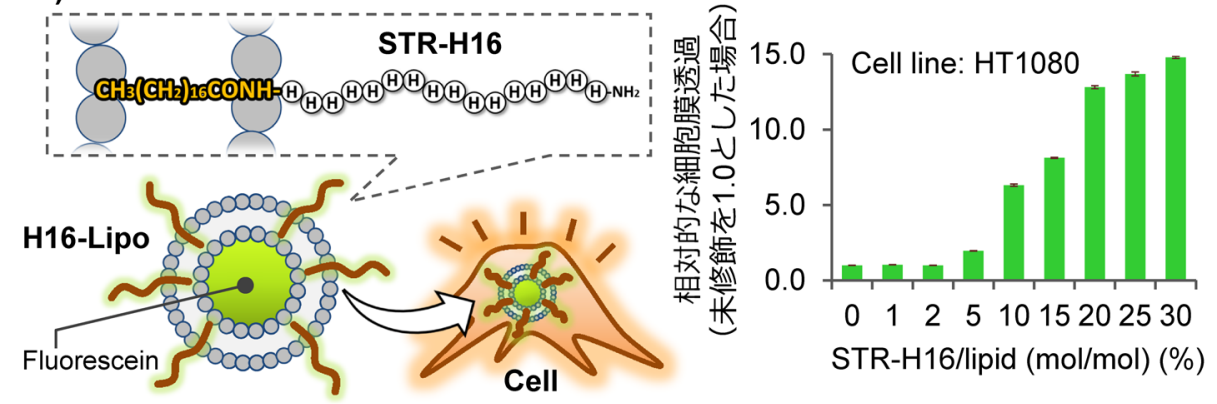

図3.（A） PolyHis(H16）のタンパク質輸送能. PolyHis(H16）を融合したタンパク質は既存のHis-Tag用アプリケーションが適用可能で ある. RFP-H16の細胞膜透過は, RFP-H16をHT1080細胞に添加し，3時間後にフローサイトメーターにより定量解析した（B）PolyHis （H16）のリポソーム輸送能. Fluorescein 内包H16-Lipo の細胞膜透過は, H16-LipoをHT1080細胞に添加し，3時間後にフローサイトメー ターにより定量解析した。 


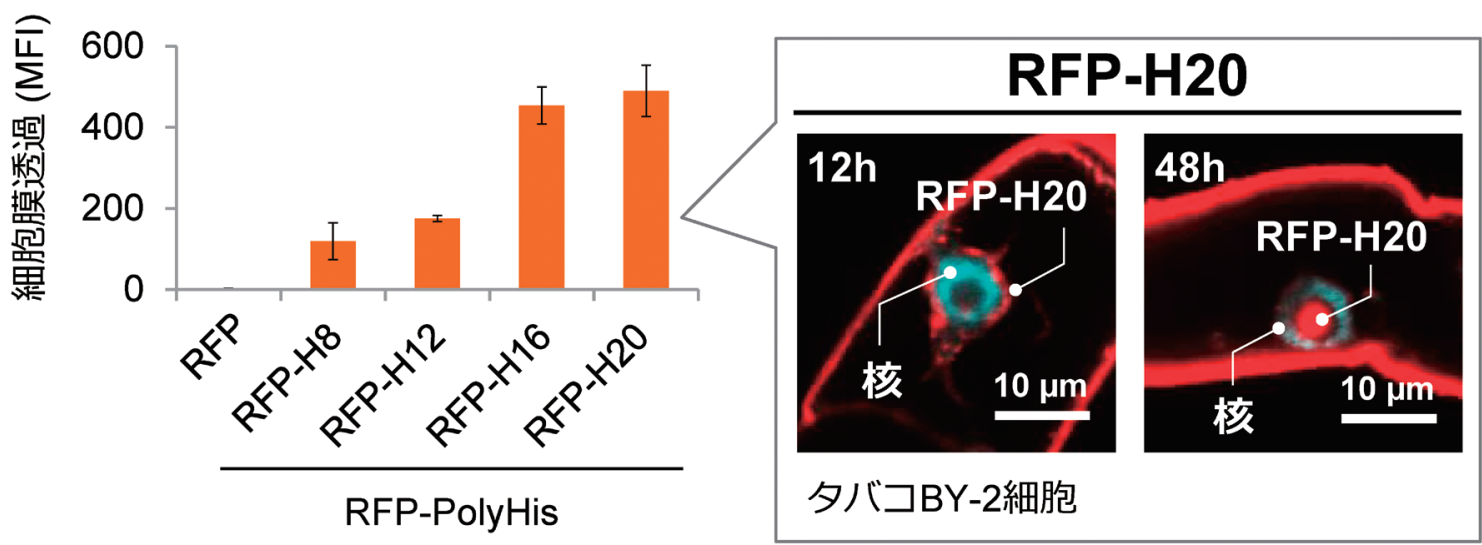

図4. 植物細胞に対するPolyHisのタンパク質輸送能. タバコBY2 細胞に対してPolyHis 融合RFP 添加し，12時間後に細胞壁を除去し， 細胞内の蛍光量を定量した. また， RFP-H20をタバコ BY2 細胞に処理し，細胞内局在を共焦点レーザー顕微鏡下で観察した。赤色蛍光は RFP-H20，青色蛍光は核（Hoechst染色）を示す.

しない新しいタイプのCPPであることから，細胞壁を有す る植物細胞に対しても有効な細胞膜透過を示す可能性が期待 された，そこで我々は，PolyHisの植物細胞に対する細胞膜 透過を評価し, 植物細胞に対する応用性について検証した。

まず，タバコBY-2細胞を使用して，PolyHisのタンパク 質輸送能を調べた。様々な鎖長の PolyHis（ヒスチジン 8〜 20残基）を融合したRFPを遺伝子工学的に調製し，タバコ BY-2細胞に処理した結果，ヒスチジン 20 残基（H20）を融 合したRFP-H20がもっとも高い細胞膜透過を示した。さら に面白いことに, タバコBY-2細胞にRFP-H20を処理してか ら 12 時間後にはRFP-H20 は細胞質中に確認されたのに対し て，48時間後にはRFP-H20が核内に移行していることが確 認された（図4)。この結果は, PolyHis(H20) が植物細胞に 対して有効な細胞膜透過ペプチドであることを示すと同時 に, PolyHis(H20) を利用することでタンパク質を植物細胞 の核内まで輸送できることを示唆するものである，この結果 を受け，我々は，PolyHis(H20）にDNA結合タンパク質を 融合することで, PolyHis（H20）を利用した植物細胞に対す る遺伝子導入技術の開発に挑戦した。

\section{PolyHis を利用した植物遺伝子導入技術の開発}

遺伝子導入技術は，基礎・応用研究を問わず多方面で利用 されつつあり，現代に打ける必須基盤技術である。しかし， 植物を対象とした従来の遺伝子導入技術には, 導入効率が必 ずしも高くないという『効率の悪さ』に加え, 適用可能な生 物種が限定されている『汎用性の低さ』という二つの致命的 な課題が存在している.この最大の理由として, 従来の遺 伝子導入技術では, アグロバクテリウムによる『植物細胞へ の感染 $=$ 植物細胞内への遺伝子導入』を必須のプロセスと している点が挙げられる，従来法では，アグロバクテリウム の細胞内で, DNA とタンパク質 (VirD2, VirE2) の複合体 （これを T-DNA 複合体と呼ぶ）を発現させ，アグロバクテリ
ウムを植物細胞に感染させることで，このT-DNA複合体を 植物細胞内に導入する手法がとられている. しかし, 植物細 胞側の防御反応によりアグロバクテリウムが感染しにくい植 物種や，そもそもアグロバクテリウムが感染できない植物種 では, 遺伝子の導入効率が悪い, または遺伝子導入自体がで きないという問題点が存在する。

そこで筆者らは, 上記の律速段階（アグロバクテリウムに よる植物細胞内への遺伝子導入のプロセス）を，植物細胞に 有効な細胞膜透過ペプチド PolyHis(H20) で代替することに より,アグロバクテリウムの感染に頼らずに，植物細胞内に 遺伝子を直接導入する『直接導入法』を考案した（図 5$)$. 本 手法は，まずT-DNA複合体を構成するVirD2 と VirE2 の両 タンパク質にPolyHis(H20) を融合した状態で発現し，次い

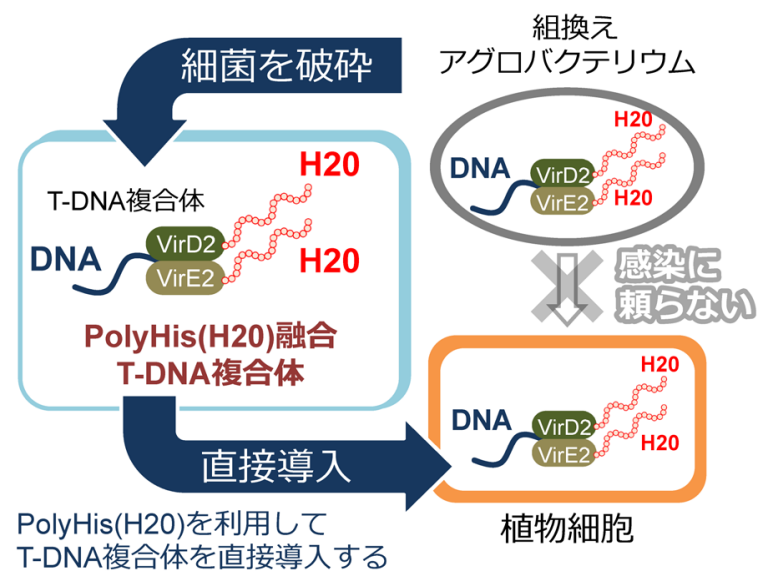

図5. PolyHis (H20) を利用した植物遺伝子導入法『直接導入 法』の概要図. 本手法では，アグロバクテリウム菌体内におい て, T-DNA 複合体を構成するVirD2 と VirE2 の両タンパク質に PolyHis (H20) を融合した状態で発現させる，次いで，アグロバ クテリウムを菌体破砕することでPolyHis(H20) 融合T-DNA複 合体を抽出し，植物細胞に導大する。これにより，アグロバクテ リウムの感染を介さずに，T-DNA複合体を植物細胞に直接導入 することができる。 
でPolyHis(H20）が融合したT-DNA複合体をアグロバクテ リウムから抽出し, 植物細胞に直接導入するという手法であ る.この直接導入法では, 従来の遺伝子導入技術のボトル ネックである『アグロバクテリウムの植物細胞への感染』を 必要としないため, 従来法と比べて遺伝子導入効率が高く, また幅広い植物種に利用可能な高い汎用性を有していること が期待される.

PolyHis（H20）を利用した直接導入法の有効性を評価する ために, VirD2-H20 と VirE2-H20を発現する組換えアグロ バクテリウムを構築した。この際，遺伝子導入を評価する ためのレポーター遺伝子として, Luciferase（Luc）遺伝子を 利用した。この組換えアグロバクテリウムに対して Acetosyringoneを処理することで，菌体内で PolyHis(H20) 融合 T-DNA 複合体（Luc 遺伝子含有）の形成を誘導した。その 後, 菌体を破砕し, 菌体破砕液を滅菌フィルター処理するこ とにより, PolyHis(H20) 融合T-DNA複合体を含んだ，ア グロバクテリウム抽出液を得た。このアグロバクテリウム抽 出液をタバコ BY-2 細胞に処理することで, 直接導入法の評 価・実証を試みた。

その結果, PolyHis(H20) 融合T-DNA複合体をタバコ BY-2 細胞に処理してから，わずか 3 時間後には導入遺伝子 （Luc遺伝子）の発現が確認され，その後も安定した遺伝子 発現が観察された（図6).アグロバクテリウム感染を利用 した従来の遺伝子導入法では, アグロバクテリウム感染から 導入遺伝子の発現が確認されるまでに数日（3日以上）を要 することが知られている. 一方で, 筆者らが今回開発した直 接導入法において, このような即効性が確認された理由とし て, 直接導入法ではアグロバクテリウムの感染というプロセ スを必要とせず，効率的（迅速）な遺伝子導入が実現できた ためであると考えられる. ${ }^{14)}$

上記のように, アグロバクテリウムに頼らない遺伝子組 換え法である『直接導入法』について，モデル植物種であ るタバコ BY-2細胞を使用して実証することができた。しか

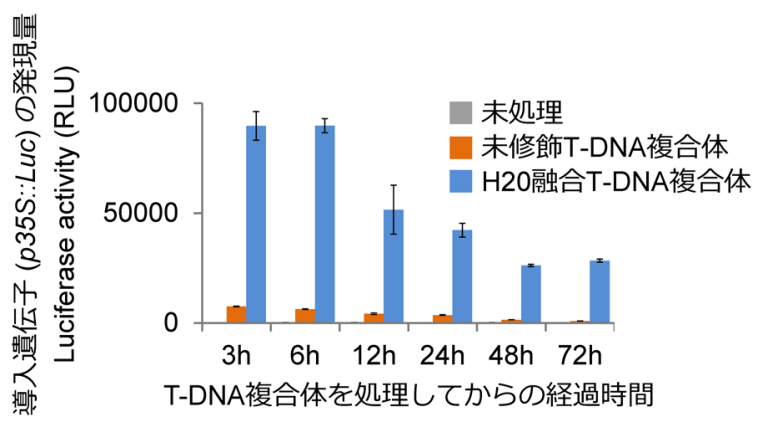

図6.『直接導入法』による導入遺伝子の発現. $35 \mathrm{~S}$ プロモー ター配列とLuc遺伝子を含んだ PolyHis(H20) 融合T-DNA 複合 体を調製し，タバコBY-2細胞に処理した。 その後, Nano-Glo （Promega社）を基質として使用することで, Luciferaseの発現 量を経時的に定量した.
し, 現在地球上で栽培されている大部分の有用植物種はいわ ゆる非モデル植物種に分類される.ゆえに，今後はPolyHis （H20）を利用した『直接導入法』が非モデル植物種に有効 であるかを評価し，非モデル植物種に有効な育種技術の開 発・改良に尽力していく所存である.

\section{ま と $\quad め$}

本研究を通じて, 筆者らは新しいCPPとして PolyHis を発 見した. 動物細胞に対しては, PolyHis(H16) が高い細胞膜 透過を示し，タンパク質やリポソームといった高分子を細胞 内へ輸送可能であることや, 生体内では腫瘍ターゲティン グ能を発揮することを明らかにした。一方で，植物細胞の ように細胞壁を有する細胞に対しては，より長鎖の PolyHis （H20）がタンパク質輸送に有効であることを明らかにした. さらに，このPolyHis(H20）を利用することで，アグロバク テリウムに頼らずに植物細胞に遺伝子を導入する直接導入法 を開発した。

今後は, 特に植物細胞を対象とした分子輸送技術の開発に 注力していく予定である。具体的には, PolyHisを利用して 植物細胞にゲノム編集酵素を輸送することで, 遺伝子組換え を介さずにゲノム編集を実現する手法や，花成ホルモンのよ うな生理活性物質を導入することで, 植物の生長を制御する 技術の開発に挑戦していきたいと考えている.

\section{謝辞}

本研究の一部は, キャノン財団, アステラス病態代謝研究 会, 高橋産業経済研究財団, 加藤記念バイオサイエンス振興 財団, 住友電工グループならびに文部科学省（科研費）の支 援のもと遂行したものです。この場をお借りして，心より感 謝を申し上げます。また, 本稿執筆の機会を賜りました農薬 学会の先生方にも, 厚く御礼を申し上げます.

\section{引 用 文 献}

1) D. Derossi, A. H. Joliot, G. Chassaing and A. Prochiantz: J. Biol. Chem. 269, 10444-10450 (1994).

2) E. Vives, P. Brodin and B. Lebleu: J. Biol. Chem. 272, 16010-16017 (1997).

3) S. Futaki, T. Suzuki, W. Ohashi, T. Yagami, S. Tanaka, K. Ueda and Y. Sugiura: J. Biol. Chem. 276, 5836-5840 (2001).

4) G. M. Poon and J. Gariepy: Biochem. Soc. Trans. 35, 788-793 (2007).

5) S. Futaki, I. Nakase, A. Tadokoro, T. Takeuchi and A. T. Jones: Biochem. Soc. Trans. 35, 784-787 (2007).

6) K. Melikov and L. V. Chernomordik: Cell. Mol. Life Sci. 62, 27392749 (2005).

7) J. G. Pan and T. W. Mak: Sci. STKE 2007, e14 (2007).

8) I. F. Tannock and D. Rotin: Cancer Res. 49, 4373-4384 (1989).

9) T. Iwasaki, Y. Tokuda, A. Kotake, H. Okada, S. Takeda, T. Kawano 
and Y. Nakayama: J. Control. Release 210, 115-124 (2015).

10) 岩崎 崇, 徳田佳久, 小竹彩香, 河野 強 (鳥取大学) : 特許第 6202707号 (2017).

11) T. Hayashi, M. Shinagawa, T. Kawano and T. Iwasaki: Biochem. Biophys. Res. Commun. 501, 648-653 (2018).

12) T. Mizuno, M. Miyashita and H. Miyagawa: J. Pept. Sci. 15, 259263 (2009).

13) M. Chang, J. C. Chou and H. J. Lee: Plant Cell Physiol. 46, 482488 (2005).

14）岩崎 崇, 河野 強, 上中弘典, 三浦千裕, 渡辺倫子, 山崎明歳 (鳥取大学)：特願2017-063568（2017）.

\section{略 歴}

岩崎 崇（いわさきたかし）

生年月日：1982年12月 1 日

最終学歴：筑波大学大学院博士後期課程

研究テーマまたは主な職歴：細胞膜透過ペプチドを利用した 薬物・分子輸送技術の開発, ヒスチジンリッチな タンパク質・ペプチドの生理機能の解明. 2007年 4 月日本学術振興会特別研究員 DC, 2009年 4 月農 業生物資源研究所生体防御研究ユニット・日本学 術振興会特別研究員PD, 2010年4月鳥取大学農学 部助教, 2016年 10 月同准教授

趣味：キャンプ, 登山, 釣り, ガイナーレ鳥取の応援 